\title{
Effects of Ibogaine on Sensory-Motor Function, Activity, and Spatial Learning in Rats
}

\author{
RAYMOND P. KESNER,' PAMELA JACKSON-SMITH, CLARISSA HENRY AND KELLY AMANN \\ Department of Psychology, University of Utah, Salt Lake City, UT 84112
}

Received 14 February 1994

\begin{abstract}
KESNER, R. P., P. JACKSON-SMITH, C. HENRY AND K. AMANN. Effects of ibogaine on sensory-motor function, activity, and spatial learning in rats. PHARMACOL BIOCHEM BEHAV 51(1) 103-109, 1995. - lbogaine, a naturally occurring alkaloid, has been show to reduce naloxone-precipitated withdrawal symptoms from morphine. Given the clinical possibilities, it is important to determine ibogaine's effects on sensory-motor function, activity, learning, and memory. LongEvans rats injected with doses of $20-60 \mathrm{mg} / \mathrm{kg}$ of ibogaine displayed slower response times on sensory and sensory-motor tests and were impaired in performing specific motor reflexes at doses of $40-60 \mathrm{mg} / \mathrm{kg}$. Furthermore, these rats showed a marked reduction in locomotor and nonlocomotor activity, as well as emotionality at doses ranging from $10-40 \mathrm{mg} / \mathrm{kg}$. At the higher doses the rats appeared to be virtually inactive. There were also deficits in learning a spatial location task (a dry-land version of the Morris water-maze). The deficits, however, were probably due to a reduction in locomotor activity and reduction in detection of sensory information. In a final experiment, a single injection of $40 \mathrm{mg} / \mathrm{kg}$ of ibogaine had marked deleterious effects on the acquisition of the spatial location lask 1 but not 7 days afler the injection, even though in this case there were no effects on sensory motor function 1 or 7 days after the injection. Thus, there are severe sensory-motor activity and learning problems while the animal is under the intluence of ibogaine (acute effect) as well as long-term consequences on learning without concomitant changes in sensory-motor function.
\end{abstract}

Ibogaine Sensory-motor function Spatial learning Morphine Withdiawal Water maze

IBOGAINE is a drug produced by extraction from the roots of Tabernanthe iboga, a plant commonly found in Africa. There is anecdotal evidence that one injection of ibogaine eliminates addiction to drugs such as heroin, morphine, and cocaine. There has not been a large number of animal studies with ibogaine. In one study, ibogaine was given to rats that had been trained to bar press for morphine, and was found to produce a dose-related decrease in bar pressing (4). This effect wils obscrved for up to several days after a single administralion.

In a different study, a single injection of ibogaine decreased cocianc self-administration for several days, and with repeated ibogąine injections cocaine intake was significantly decreased for weeks (1). Ibogaine also has been shown to reduce the effects of naloxone-precipitated withdrawal symptoms from morphine (5).

It has been shown that development of drug tolerance, drug addiction, withdrawal from drug addiction, and drug craving are influenced not only by mechanisms of reward and incentive motivation, but also by mechanisms of learning and memory. Current theories have proposed that operant and classical conditioning, habituation, and sensitization play a very important role in determining the level of dr ug tolerance, drug addiction, drug withdrawal, and drug craving $(7,12$, $14,16)$. It is therefore possible that the inhibitory effects of ibogaine on drug addiction and drug craving might be due to a general interference with learning and memory processes. The hippocampus is known to play an important role in learning and memory $(3,6,17)$. It was therefore of real interest to discover that rats will self-administer dynorphin A (opiate agonist) injected directly into the $\mathrm{CA}_{3}$ region of the hippocampus (18). The authors suggest that craving and compulsive drug seeking may depend on memory for past drug reinforcements, and because the hippocampus is important in learning and memory, it may play a critical role in drug addiction and drug craving. The possibility exists that ibogaine's blockade of

\footnotetext{
To whom requests for reprints should be addressed.
} 
drug addiction is due in part to its actions on the hippocampus, and therefore on learning and memory processes. The purpose of the present study was to test this idea by selection of a spatial navigation learning lask that is known to be scnsilive lo hippocampal dysfunction (9). However, before we could examine the effects of ibogaine on spatial navigation learning, it was necessary to determine the effects of different doses of ibogaine on sensory motor function as well as general activity level, so that the appropriate doses could be selected for the learning study.

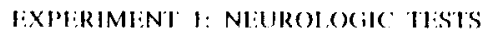

\section{Methods}

The subjects consisted of eight naive male Long-Evans rats, approximately 100 days old. Each animal was given the entire battery of neurologic tests, once per day for a block of 4 consecutive days. Following a 3 -day interval, the rats were again given a block of four consecutive sessions. Each animal was injected with either $10,20,30,40,50$, or $60 \mathrm{mg} / \mathrm{kg}$ [intraperitoneally (IP)] of ibogaine or vehicle (sterile water) $30 \mathrm{~min}$ before testing each day. Ibogaine was supplied by NIDA. Every animal was tested once with each drug dose and twice with vehicle. Half of the rats received low doses of ibogaine $(0,10$, 20 , and $30 \mathrm{mg} / \mathrm{kg}$ ) on the first block of four sessions, and the higher doses $(0,40,50$, and $60 \mathrm{mg} / \mathrm{kg})$ on the second block of four sessions. For purposes of counterbalancing the effects of ibogaine, the other four rats received the higher doses on the first block and the lower doses on the second block of four sessions using a Latin square design. The animals were placed in a small box $(30 \times 45 \times 10 \mathrm{~cm})$ and allowed $10 \mathrm{~s}$ to adjust to the surroundings before each of the neurologic tests was administered.

\section{Sensory Tests}

Visual stimulus orienting test. A $5 \ldots 5-\mathrm{cm}$ cardboard square with a checkered pattern of black and white, $2.5 \mathrm{-cm}$ squares attached to a wooden stick was used. This square was held in the peripheral field of vision on either side of the animal's head. A response was defined as orienting to the checkered square, and the latency to respond was measured by a second experimenter using a stopwatch. A maximum score of $60 \mathrm{~s}$ was given when the animal failed to respond. Two measurements were taken one from the right and the other from the left of the rat. The average of the two latencies was used as a measure of visual detection.

Whisker touch orienting test. A cotton swab was brought from behind the animal's head and put in contact with the vibrissae. The vibrissae were continually stimulated while the swab was held outside the rat's field of vision until a response occurred or a maximum of $60 \mathrm{~s}$ was reached. The test was given successively on each of the rat's right and left sides. The latency to respond (orient toward the swab) was measured. The average latency of the two responses was used as a measure of whisker touch detection.

Olfactory orienting test. Twenty-one different distinctive scents, including, for example, mint, lemon, and root beer, were used in this test. To decrease the possibility of tolerance, the odors were randomly chosen for each test with no repetition within a 4-day block. A cotton swab was moistened with the preselected scent and brought from behind the animal's licad, so that it remained out of the field of vision and did not touch the animal. Each of the rats was exposed to two scents, both of which were presented from its right and left sides. The latency to orient was recorded and the average of the four tests was used as a measure of olfactory detection.

Somatosensory orienting test. A thin wirc $(30 \mathrm{~cm}$ long) was applied to and held against the animal's shoulders, midsection, and hind guarters (with gentle pressure) on both right and left sides. The animal's latency to orient to each touch was recorded, and the average of the six response times was used as a measure of somatosensory detection.

\section{Sensory-Motor Tests}

Placing reflex test. The rat was first suspended by the tail and then brought to the edge of a table. Normal animals reach for the edge of a table by forelimb extension when brought within reach of it. When the animal responded using only the sight of the table, the animal was given a score of 1; when it required touch of the vibrissae to the table, the score was 0.75 ; when it required touch of the snout, the score was 0.50 ; and when it required additional touching of the snout to the table, the score was 0.25 . When no response was elicited, the score given was 0 .

Titled platform test. Each animal was placed at the center of a $30 \times 30-\mathrm{cm}$ plywood platform covered with carpet. The platform was tilted at $30^{\circ}$ and the animal was placed with its head pointing toward the low end. Normal animals respond by turning uphill facing the high end of the platform. The latency to turn around and face uphill perpendicular to the front end was measured, and a maximum score of $60 \mathrm{~s}$ was used.

\section{Motor Tests}

Grasping reflex. Each animal was suspended by the nape' of the neck, and both front feet were touched by a single piece of thin wire. The rating scale used was a score of 1 for grasping the wire and 0 for no response. A normal animal will flex its digits around the wire, grasping tightly.

Righting reflex (back). For this test each animal was placed on its back and released. When the animal righted itself, a score of 1 was given. When the animal failed to right itself, a score of 0 was given.

Righting reflex (free fall). Each animal was held upside down $20 \mathrm{~cm}$ above a foam pad and released. When the animal righted itself in midair, landing on its feet, a score of 1 was given. When the animal failed to right itself completely, a score of 0 was given.

\section{RESUI TS}

The effect of ibogaine injections on mean latency to respond to the visual stimulus is shown in Table 1 . As doses of ibogaine increased from $0-60 \mathrm{mg} / \mathrm{kg}$ there was a corresponding increase in latency to respond to the visual stimulus. A one-way within-subject analysis of variance (ANOVA) indicated that there was a significant drug dose effect $[F(6,114)$ $=16.7, p<0.0001]$. Further Newman-Keuls tests revealed that doses of $30,40,50$, and $60 \mathrm{mg} / \mathrm{kg}$ of ibogaine resulted in significantly $(p<0.01)$ longer latencies in comparison with vehicle control $(0 \mathrm{mg} / \mathrm{kg})$.

Table 1 also shows the effect of ibogaine injections on latency to respond to the olfactory stimulus. As the table indicates, as doses of ibogaine increased there was a corresponding increase in latency to respond to the offactory stimulus. A one-way within-subject ANOVA indicated that there was a significant drug dose effect $[F(6,114)=25.4, p<0.0001]$. Further Newman-Keuls tests revealed that doses of 20, 30, 40, 
TABLE I

EFFECTS OF IBOGAINE INJECTION ON PERFORMANCE OF SPECIIIC MEMORY TASKS

\begin{tabular}{|c|c|c|c|c|c|c|c|}
\hline \multirow[b]{2}{*}{ Tests } & \multicolumn{7}{|c|}{ Latency to Respond (s) } \\
\hline & 0 & 10 & 20 & 30 & 40 & 50 & 60 \\
\hline Visual stimulus & $1.4 / 0.6$ & $3.0 / 2.2$ & $2.8 / 0.7$ & $4.7 / 1.2$ & $9.2 / 2.0$ & $10.2 / 3.0$ & $12.6 / 2.8$ \\
\hline Olfactory stimulus & $3.0 / 0.6$ & $4.6 / 1.9$ & $10.4 / 1.6$ & $9.4 / 1.3$ & $17.5 / 2.1$ & $12.2 / 1.2$ & $14.0 / 2.3$ \\
\hline Somatosensory stimulus & $1.5 / 0.3$ & $2.0 / 0.9$ & $2.3,0.7$ & $3.2 / 0.6$ & $3.7 / 0.8$ & $7.1 / 2.0$ & $5.9 / 1.9$ \\
\hline Whiska-louch stimulus & $0.7 / 0.2$ & $3.6 / 1.3$ & $6.4,1.5$ & $4.6 / 1.0$ & $16.3 / 2.5$ & $10.6 / 3.1$ & $11.0 / 3.6$ \\
\hline Tilted platform & $13.5 / 3.6$ & $32.1 / 15.0$ & $28.7 / 7.2$ & $23.9 / 5.2$ & $33.0 / 5.2$ & $18.3 / 4.4$ & $31.7 / 9.0$ \\
\hline
\end{tabular}

Dala are means/SE $(\mathrm{mg} / \mathrm{kg})$.

50, and $60 \mathrm{mg} / \mathrm{kg}$ of ibogaine resulted in significantly $(p<$ $0.01)$ longer latencies in comparison with vehicle control.

The effect of ibogaine injections on mean latency to respond to the somatosensory stimulus is also shown in Table 1. As doses of ibogaine increased there was a corresponding increase in latency to respond to the somatosensory stimuli. A one-way within-subject ANOVA indicated that there was a significant drug dose effect $[F(6,114)=14.2, p<0.0001]$. Further Newman-Keuls tests revealed that doses of 30, 40, 50, and $60 \mathrm{mg} / \mathrm{kg}$ of ibogaine resulted in significantly $(p<0.05)$ longer latencies in comparison with vehicle control.

Table 1 also shows the effect of ibogaine injections on mean latency to respond to whisker touch. As doses of ibogaine increased, there was a corresponding increase in latency to respond to the whisker touch stimulus. A one-way withinsubject ANOVA indicated that there was a significant drug dose effect $[F(6,114)=20.3, p<0.0001]$. Further Newman-Keuls tests revealed that doses of $20,30,40,50$, and 60 $\mathrm{mg} / \mathrm{kg}$ of ibogaine resulted in significantly $(p<0.01)$ longer latencies in comparison with vehicle control.

Finally, the effect of ibogaine injections on mean latency to respond to the tilted platform is shown in Table 1 . The table indicates that ibogaine produced an increase in latency to respond compared to the vehicle control condition. A one-way within-subject ANOVA revealed that there was a significant drug dose effect $[F(6,114)=4.36, p<0.0005]$. Further Newman-Keuls tests revealed that at all doses but the $50 \mathrm{mg}$ / $\mathrm{kg}$ dose of ibogaine the rats had significantly $(p<0.05)$ longer latencies in comparison with vehicle control rats.

The effect of ibogaine injections on the mean placing reflex score is shown in Table 2 . Ibogaine disrupted the appropriate execution of the placing reflex only at the $50-\mathrm{mg} / \mathrm{kg}$ ibogaine dose. A one-way within-subject ANOVA revealed that there was a significant drug dose effect $[F(6,114)=12.1, p<$
$0.001]$. Further Newman-Keuls tests indicated that the dose of $50 \mathrm{mg} / \mathrm{kg}$ of ibogaine resulted in a significantly lower score compared to all the other doses $(p<0.01)$.

The effect of ibogaine injections on the mean grasping reflex score is also shown in Table 2. Ibogaine disrupted the appropriate execution of the grasping reflex only at the 40and $50-\mathrm{mg} / \mathrm{kg}$ ibogaine doses. A one-way within-subject ANOVA revealed that there was a significant drug dose effect $[F(6,114)=3.4, p<0.004]$. Further Newman-Keuls tests indicated that doses of 40 and $50 \mathrm{mg} / \mathrm{kg}$ ibogaine resulted in significant lower scores compared to the other doses $(p<$ 0.01 ).

Table 2 shows the effect of ibogaine injections on the mean righting reflex (back) score. Ibogaine disrupted the execution of the righting reflex starting at doses of $40 \mathrm{mg} / \mathrm{kg}$ ibogaine and above. A one-way within-subject ANOVA revealed that there was a significant drug dose effect $[F(6,114)=11.4, p$ $<0.0001]$. Further Newman-Keuls tests indicated that doses of 40,50 , and $60 \mathrm{mg} / \mathrm{kg}$ of ibogaine resulted in significantly lower scores compared to the other doses $(\rho<0.01)$.

Finally, the effect of ibogaine injections on mean free fall righting reflex score is shown in Table 2 . Ibogaine disrupted the execution of the righting reflex (free fall) starting at doses of $30 \mathrm{mg} / \mathrm{kg}$ ibogaine and above. A one-way within-subject ANOVA revealed that there was a significant drug dose effect $[F(6,114)=5.1, p<0.0001]$. Further Newman-Keuls tests indicated that doses of $30,40,50$, and $60 \mathrm{mg} / \mathrm{kg}$ of ibogaine resulted in significantly lower scores compared to 0,10 and 20 $\mathrm{mg} / \mathrm{kg}$ ibogaine $(p<0.05)$.

\section{Discussion}

The results point to a reduction in detection of sensory information as indicated by longer latencies to respond. This

TABLE 2

EFFECTS OF IBOGAINE INJECTION ON PERFORMANCE OF SPECIFIC MOTOR TASKS

\begin{tabular}{lccccccc}
\hline & \multicolumn{7}{c}{ Performance Score } \\
\cline { 2 - 8 } \multicolumn{1}{c}{ Tests } & 0 & 10 & 20 & 30 & 40 & 50 & 60 \\
\hline Placing reflex & $1.0 / 1.0$ & $1.0 / 1.0$ & $1.0 / 1.0$ & $1.0 / 1.0$ & $1.0 / 1.0$ & $0.8 / 0.1$ & $1.0 / 1.0$ \\
Grasping reflex & $1.0 / 1.0$ & $1.0 / 1.0$ & $1.0 / 1.0$ & $1.0 / 1.0$ & $0.9 / 0.1$ & $0.9 / 0.1$ & $1.0 / 1.0$ \\
Righting reflex (back) & $1.0 / 1.0$ & $1.0 / 1.0$ & $1.0 / 1.0$ & $1.0 / 1.0$ & $0.8 / 0.1$ & $0.9 / 0.1$ & $0.6 / 0.2$ \\
Righining reflex (fill) & $1.0 / 1.0$ & $10 / 1.0$ & $1.1 / 1.0$ & $0.1 / 0.1$ & $0.9 / 01$ & $0.9 / 01$ & $0 \% / 02$
\end{tabular}

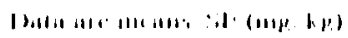


reduction in sensory responsiveness was already evident at doses of $20 \mathrm{mg} / \mathrm{kg}$ of ibogaine for the olfactory and whiskertouch oricnting lests. At doses of $40 \mathrm{mg} / \mathrm{kg}$ ibogaine, reduction in detection of sensory information was observed in all of the sensory assessment tests. Furthermore, in general, the higher the dose of ibogaine the greater the sensory impairment. Thus, ibogaine has a marked disruptive effect on detection of seusory input.

With respect to sensory-motor function, ibogaine disrupted performance on the tilted platform test at the lowest dose $(10 \mathrm{mg} / \mathrm{kg})$. This test is sensitive to vestibular and cerebellar function and is consistent with a recent report that ibogaine has deleterious actions on cerebellar function (13). With respect to tests of motor function, in general, problems did not appear until doses of $40-50 \mathrm{mg} / \mathrm{kg}$ ibogaine.

Thus, ibogaine appears to have its greatest effects on tests of vestibular and cerebellar function, followed by effects on sensory function, and then motor functions.

\section{EXPERIMENT 2: ACTIVITY AND FMOTIONAIITY}

The rats under the influence of ibogaine were not very active. It was thus important to employ a standard test of activity to quantify the effects of ibogaine on the level of activity.

The effect of ibogaine $(0,10,20,30$, or $40 \mathrm{mg} / \mathrm{kg})$ on activity and emotionality was assessed in an open field. Because doses of 50 and $60 \mathrm{mg} / \mathrm{kg}$ ibogaine severely impaired motor responses, these dose levels were not used in the activity experiment.

\section{Methods}

The apparatus used was a large, open wooden box $(120 \times$ $120 \mathrm{~cm}$ ) with $30-\mathrm{cm}$-high walls. The floor of the box was painted white and divided by black lines forming 64 square sections $(15 \times 15 \mathrm{~cm})$. The subjects were 40 Long-Evans rats, deprived to and maintained at $80-85 \%$ of free-feeding body weight. For the open field experiment, eiglıt rats in each group were assigned a dose $(0,10,20,30$, or $40 \mathrm{mg} / \mathrm{kg})$ of ibogaine, which remained consistent throughout the testing period. Thirty minutes after IP injection, each animal was placed in the center of the open field for $10 \mathrm{~min}$. The mean number of squares entered was used as a measure of locomotor activity. Grooming, scratching, righting, and washing behaviors were recorded and combined into a single nonlocomotor activity score. Emotionality was measured by the occurrence of urination and defecations, and these were combined for an emotionality score. Testing was conducted on each of 3 consecutive days.

\section{Results}

The effect of ibogaine injections on locomotor activity (mean squares traversed) as a function of days of testing is shown in Fig. 1. Ibogaine produced a dose-dependent decrease in locomotor activity compared to the vehicle control. A twoway ANOVA with dose level as the between factor and days as the within factor revealed a significant drug effect $[F(4,20)$ $=8.1, p<0.0005]$ and a significant days effect $[F(2,40)=$ $3.27, p<0.05$ ]. A subsequent Newman-Keuls test revealed that all ibogaine groups displayed significantly $(p<0.05)$ lower locomotor activity compared to the vehicle control.

The effect of ibogaine injections on nonlocomotor activity (grooming, scratching, washing, and righting) as a function of days of testing is shown in Fig. 2. Ibogaine produced a

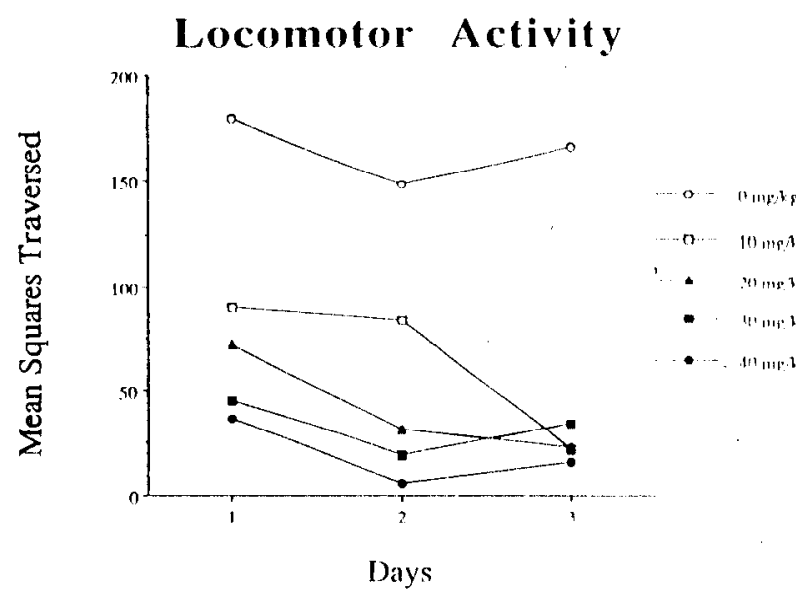

FIG. 1. The effect of ibogaine $(\mathrm{mg} / \mathrm{kg}$ ) on mean number of squar traversed as an index of locomotor actvity as a function of days.

dose-dependent decrease in nonlocomotor activity comparı to the vehicle control. A two-way ANOVA with dose level the between factor and days as the within factor revealed significant drug effect $[F(4,20)=13.5, p<0.0001]$ and significant days effect $[F(2,40)=5.29, p<0.009]$. A subs quent Newman-Keuls test revealed that all ibogaine grou displayed significantly $(p<0.05)$ lower nonlocomotor acti ity compared to the vehicle control.

The effect of ibogaine injections on urination and defec tion as a function of days of testing is shown in Fig. 3. Ib gaine produced a decrease in urination and defecation (em tionality) compared to the vehicle control. A two-w: ANOVA with dose level as the between factor and days as $t$ within factor revealed a significant drug effect $[F(4,20)$ $7.5, p<0.025$ ].

\section{Discussion}

The results indicate that ibogaine produces a dos dependent reduction in locomotor activity and nonlocomot. activity as well as urination and defecation. The rats receiviı

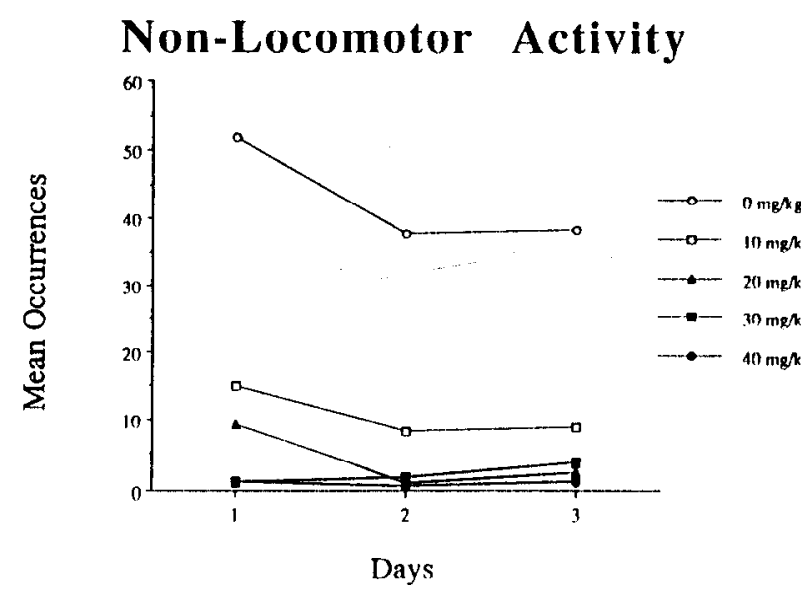

FIG. 2. The effect of ibogaine ( $\mathrm{mg} / \mathrm{kg}$ ) on the mean number of $\mathrm{o}$ currences of washing, righting, scratching, and grooming as an ind of nonlocomotor activity as a function of days. 


\section{Emotionality}

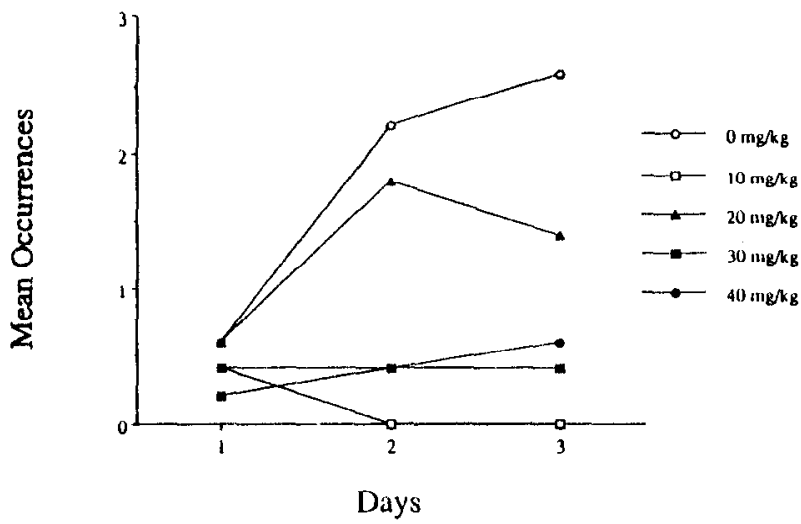

FIG. 3. The effect of ibogaine $(\mathrm{mg} / \mathrm{kg}$ ) on the mean number of occurrences of urination and defecation as an index of emotionality as a function of days.

the higher doses $(30-40 \mathrm{mg} / \mathrm{kg}$ ) of ibogaine were very inactive and appeared to be in a state of suspension. These results are consistent with the observation of reduced locomotor activity in mice injected with $80 \mathrm{mg} / \mathrm{kg}$ of ibogaine (15). It has been shown that ibogaine produces immediate and delayed changes in dopamine metabolism in nucleus accumbens, striatum, and pref rontal cortex and that these changes relate to decreases in morphine-induced locomotor activity (11). Thus, it is likely that changes in locomotor activity are due to ibogaine action on dopaminergic brain systems. The enhanced efficacy in reducing activity levels for the $10-\mathrm{mg} / \mathrm{kg}$ group with repeated treatments could have been due to cumulative effects of the drug. Furthermore, the ibogaine-injected rats were less emolional compared to the vehicle-injected rats. This is significant because it indicates or suggests that the reduced activity of ibogaine-injected rats was not a result of an enhanced fear response to the open field. It is not clear why the $20-\mathrm{mg} / \mathrm{kg}$ ibogainc-injected rats showed greater emotionality compared to the $10-\mathrm{mg} / \mathrm{kg}$ group.

\section{EXPLRIMLNI 3: LEARNING TASKS}

Even though ibogaine has marked effects on detection of sensory stimuli and reduces activity level, it was still important 10 determine whether these effects would lead to learning and memory problems. To measure the effects of ibogaine on learning and memory, rats were trained on a spatial location memory lask in a dry-land version of a water maze. This task has been shown to be sensitive to hippocampal dysfunction.

\section{Methods}

- Apparatus. The apparatus (cheeseboard) was made of 3.3cm-thick wood, painted white and elevated $26 \mathrm{~cm}$ from the floor. It was circular with a diameter of $119 \mathrm{~cm}$. It contained 177 evenly spaced, round holes $(2 \mathrm{~cm}$ in diameter and $1.5 \mathrm{~cm}$ deep) spaced $4 \mathrm{~cm}$ apart. The walls of the room contained pictures as extramaze visual cues. The trials were monitored by a video camera positioned directly above the maze, which fed into a tracking system consisting of an image analyzer (HVS Lid. VP 110) coupled to an Apple IIe computer. A light-emitting diode attached to Velcro tape was placed onto the rat's body for tracking purposes.
Behavioral procedures. Pretraining involved attaching Velcro tape to an animal and allowing it to explore the apparatus with food (Froot Loop cereal) in half of the food wells. This enabled the rats to habituate to the cheeseboard environment. The animals were familiarized with the apparatus for 6 days. After the 2 nd day the number of food wells containing Froot Loops was reduced to 35 , and on the 5 th day to 25 .

On the 7th day the animals were assigued a specific food location (one food well containing once piece of Froot Loop cereal) in one of the four quadrants of the apparatus; this location remained consistent throughout testing. Thirty minutes before testing the animals were injected with $0,10,20$, or $30 \mathrm{mg} / \mathrm{kg}$ of ibogaine; each drug-dose group contained eight subjects. The animals were given eight trials pur day with two trials at each of the four starting locations. The intertrial interval was a minimum of $5 \mathrm{~s}$. Each trial consisted of placing an animal on the edge of the apparatus facing the wall at one of the four starting locations. The animal was allowed to search for the food well containing the Froot Loop cereal until it found the correct hole and ate the food, or until $120 \mathrm{~s}$ had transpired. The latency to find the correct food well was used as the dependent measure. On the following 2 days each animal received the same drug treatment $30 \mathrm{~min}$ before testing and was given an additional eight trials using the same procedure previously described.

\section{Results}

The results are shown in Fig. 4. In the spatial location learning task, rats with 10,20 , or $30 \mathrm{mg} / \mathrm{kg}$ ibogaine injections could not learn the task, as indicated by long latencies to find the food location.

An ANOVA of the latency data with drug dose as the between-subject variable and blocks of trials as the withinsubject variable revealed a significant effect of drug dose $[F(3$, $28)=25.2, p<0.001]$ and a significant effect of blocks of trials $[F(5,140)=3.2, p<0.009]$. The observation of a significant effect of blocks without a significant interaction of drug dose and blocks indicates that all the rats improved across trials. Based on subsequent Newman-Keuls tests, rats that received ibogaine were significantly different from salineinjected rats $(p<0.01)$, but not from each other.

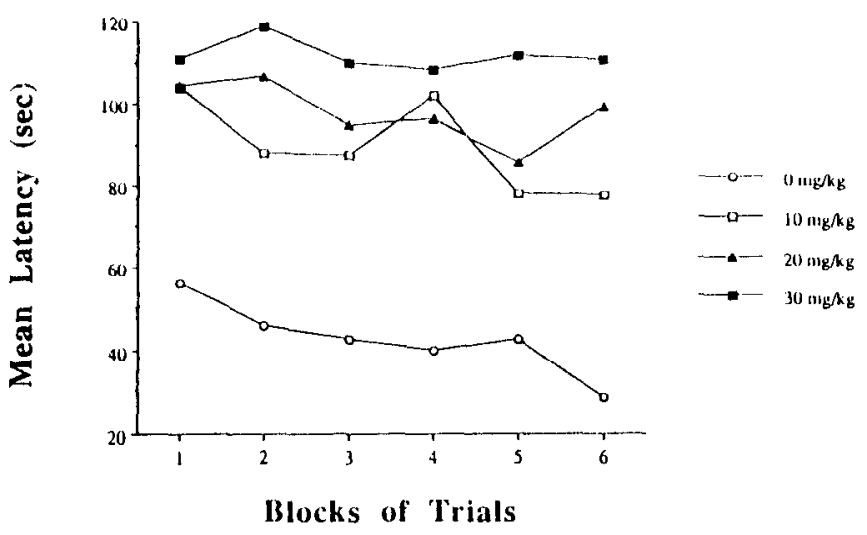

FIG. 4. The effect of ibogaine $(\mathrm{mg} / \mathrm{kg}$ ) on the mean latency (s) to find the correct food location in the spatial location task as a function of blocks of four trials (two per day). 
Misinsing

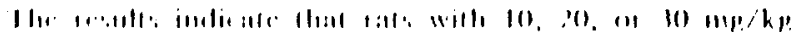

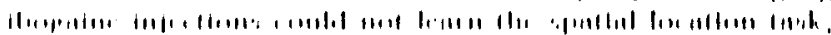

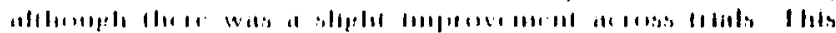
could be due in part to the reduction in locomotor activity, and thus, difficultics in a searching for the location of the food. This inability to learn could also be due to a reduction in the ability to detect visual stimuli.

Therefore, one cannot clearly assess the effects of ibogaine on lcarning and memory in this task, because of its marked cffects on activity level and sensory-motor functions.

\section{EXPERIMENT 4: LONG-TERM EFFECTS OF IBOGAINE}

Even though the acute effects of ibogaine on sensorymotor function, activity, and learning are rather profound, we needed to determine whether a single dose of ibogaine would have long-term consequences on sensory-motor function and learning of a spatial location task.

\section{Methods}

Thus, new rats $(n=30)$ were injected (IP) with either the vehicle $(n=14)$ or ibogaine $(n=16)(40 \mathrm{mg} / \mathrm{kg})$ and subsequently tested for learning of the spatial location task 1 day [vehicle $(n=9)$, ibogaine $(n=10)$ ] or 7 days [vehicle $(n=$ $5)$ and ibogaine $(n=6)$ ] later using the same procedure described in Experiment 3, the spatial location task.

In addition, of the 19 rats that were tested in the spatial location task I day later, eight (four vehicle and four ibogaine) were tested for sensory-motor function using the same procedures described in Experiment 1 before the 1st day of testing in the spatial location task, and 11 (five vehicle and six ibogaine) were tested for sensory-motor function immediately after the last day of testing (day 3 ) in the spatial location task. Of the 11 rats that were tested in the spatial location task 7 days later, all 11 (five vehicle and six ibogaine) were tested for sensory-motor function immediately after the last day of testing (day 9) in the spatial location task.

\section{Results}

After a single $40-\mathrm{mg} / \mathrm{kg}$ ibogaine injection, there were no neurologic problems on the 1-, 3-, or 10-day neurologic tests for visual and somatosensory information or motor tests (placing, grasping, and righting reflexes). Even though this was not assessed formally, the rats were not inactive 1-11 days after the ibogaine injection. As an illustration of the lack of effect of ibogaine, results are shown for the olfactory and whisker-touch sensory tests, and the tilted platform test for the velicle and $40-\mathrm{mg} / \mathrm{kg}$ ibogaine groups tested $30 \mathrm{~min}$ after injection (from Experiment 1) and vehicle or $40-\mathrm{mg} / \mathrm{kg}$ ibogaine groups tested $24 \mathrm{~h}$ after injection (Table 3). Relative to the 30 -min ibogaine-injection test, there were no problems 24 $h$ following an ibogaine injection.

A two-way ANOVA with dose ( 0 or $40 \mathrm{mg} / \mathrm{kg}$ ibogaine) and test interval ( $30 \mathrm{~min}$ vs. $24 \mathrm{~h}$ ) as the two factors was performed on latency to respond to olfactory stimuli, and revealed a significant dose effect $[F(1,41)=10.6, p<$ $0.003]$, a significant interval effect $[F(1,41)=11.2, p<$ 0.002 , and a significant dose $\times$ interval interaction $[F(1,41)$ $=9.5, p<0.004]$. A similar analysis on latency to respond to whisker touch revealed a significant dose effect $[F(1,41)=$ $11.8, p<0.002]$, a significant interval effect $[F(1,41)=5.4$, $p<0.03]$, and a significant dose by interval interaction $[F(1$, $41)=6.5, p<0.021$. A final analysis on latency to respond
IAIII: I

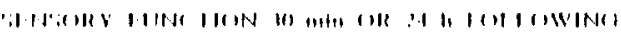

I alemey to kespond (s)

\begin{tabular}{lccccc}
\cline { 2 - 3 } \multicolumn{1}{c}{ Tests } & \multicolumn{3}{c}{30 minures } & \multicolumn{2}{c}{24 hourn } \\
\cline { 2 - 5 } \cline { 5 - 6 } & 0 & 40 & 0 & 40 \\
\hline Olfactory stimulus & $3.2 / 0.7$ & $15.7 / 3.3$ & $2.4 / 0.5$ & $2.8 / 0.7$ \\
Whisker-touch stimulus & $0.9 / 0.4$ & $11.6 / 4.1$ & $1.3 / 0.6$ & $3.6 / 2.0$ \\
Tilted platform & $21.5 / 9.7$ & $31.6 / 11.5$ & $5.3 / 1.1$ & $12.1 / 6.8$
\end{tabular}

Data are means $/ \mathrm{SE}(\mathrm{mg} / \mathrm{kg})$.

to the tilted platform revealed primarily a significant interval effect $[F(1,41)=4.5, p<0.04]$ with a dose effect almost reaching significance $[F(1,41)=3.7, p<0.06]$.

The results of a single injection of 0 or $40 \mathrm{mg} / \mathrm{kg}$ of ibogaine 1 or 7 days before testing on mean latency to find the correct food location are shown in Figs. 5 and 6 , and indicate that there was a significant disruptive effect on spatial learning 1-3 days after the ibogaine injection, but no long-term consequence 7-9 days later. An ANOVA of the latency data 1 day after injection with drug dose as the between-subject variable and blocks of trials as the within-subject variable revealed a significant dose effect $[F(1,17)=4.5, p<0.05]$, but no significant trials or significant dose $\times$ trials interaction effect. Thus, a single injection of ibogaine produced a disruption in learning the spatial location task. A similar ANOVA on the latency data 7 days after injection revealed only a significant block of trials effect $[F(5,45)=4.3, p<0.003]$, but no sig. nificant dose or significant dose $\times$ trial interaction effect, indicating that both groups learned the task.

\section{Discussion}

The results of this last experiment suggest that even thotigh ibogaine has no long-term consequences on sensory-motor function, there are significant effects on the acquisition of a spatial navigation task 1-3 days after a single injection of 40

\section{One Day Interval}

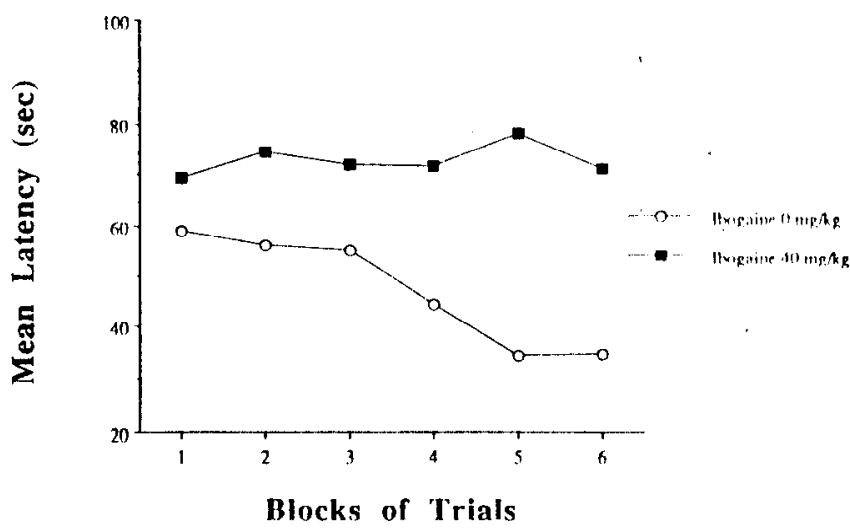

FIG. 5. Mean latency (s) to find the correct food location as a function of blocks of four trials (two per day) starting 1 day after a single injection of 0 or $40 \mathrm{mg} / \mathrm{kg}$ ibogaine. 


\section{Seven Day Interval}

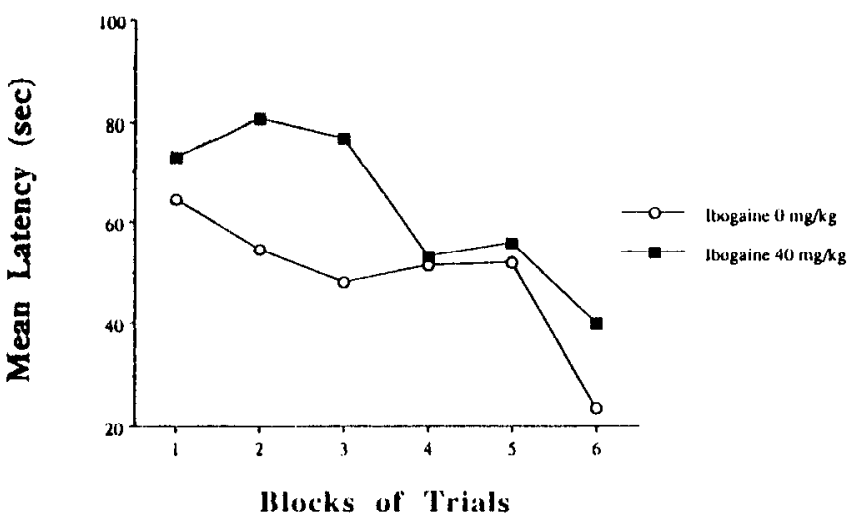

FIG. 6. Mean latency (s) to find the correct food location as a function of blocks of four trials (two per day) starting 7 days after a single injection of 0 or $40 \mathrm{mg} / \mathrm{kg}$ ibogaine.

$\mathrm{mg} / \mathrm{kg}$ of ibogaine. This long-term effect appears to be time limited, because only a small nonsignificant effect on learning was found 7-9 days after a single injection of $40 \mathrm{mg} / \mathrm{kg}$ of ibogaine.

Thus, ibogaine at doses of $10-40 \mathrm{mg} / \mathrm{kg}$ can produce marked impairments on activity, sensory-motor function, and learning while the subject is under the influence of the drug, as well as a long-term effect on learning that cannot be due to deficits in sensory-motor function or marked changes in activity level. It is not clear how ibogaine can produce long-term effects on learning ability, especially because the half-life of ibogaine in rats is about $1 \mathrm{~h} \mathrm{(2).} \mathrm{Similar} \mathrm{long-term} \mathrm{effects} \mathrm{of}$ ibogaine on behavior have been described elsewhere $(4,11)$. It is not known whether a metabolite of ibogaine has a long half-life or whether ibogaine produces long-term changes in specific neural transmitter systems. It has been shown that ibogaine can decrease the levels of dopamine metabolites at least for $19 \mathrm{~h}$ after an ibogaine injection (11).

The long-term deficits of ibogaine on the dry-land version of the water maze spatial navigation task are similar to what has been reported for rats with hippocampal lesions (9), suggesting the possibility that long-term effects of ibogaine could be based on its influence on hippocampal learning and mem ory function. It should be noted lhat ibogaine also has effects on the dopaminergic system within nucleus accumbens, prefrontal cortex, and striatum $(10,11)$, and thus could alter reward mechanisms as well. However, lesions of the striatum or medial prefrontal cortex do not produce marked deficits in spatial navigation tasks $(8,9)$. It is a possibility that ibogaine has effects on addiction via a dual action on reward as well as learning and memory mechanisms. The present study indicates that ibogaine has effects on learning and memory. Whether ibogaine affects learning and memory processes associated with tolerance development, addiction, withdrawal from addiction, and craving needs to be assessed.

\section{ACKNOWLEDGEMENTS}

This research was supported by a Professional Service Contract from NIDA.

\section{REFERENCES}

1. Cappendijk, S. I. T.; Dzoljic, M. R. Inhibitory effects of ibogainc on cocaine self-administration in rats. Eur. J. Pharmacol. (iin press).

2. Diahir, H. I. A comparative study of the toxicity of ibogaine and serotonin. Doctoral dissertation, Indiana University, Indiana Univ. Microfilms no. 71-25: 341 .

3. Eichenbaum, H.; Otto, T.; Cohen, N. J. The hippocampus: What does it do? Behav. Neural Biol. 57:2-36; 1992.

4. Click, S. S.; Rossman, K.; Steindorf, S.; Maisonneuve, I. M.; Carl son, T. N. Effect and aftereffects of ibogaine on morphine selfadministration in rats. Eur. J. Pharmacol. 195:341-345; 1991.

5. Glick, S. \$.; Rossman, K.; Rao, N. C.; Maisonneuve, I. M.; Carlson, J. N. Effects of ibogaine on acute signs of morphine withdrawal in rats: Independence from tremor. Neuropharmacology $31: 497 \ldots 500 ; 1992$.

6. Kesner, R. P. Learning and memory in rats with an emphasis on thic role of the hippocampal formation. In: Kesner, R. P.; Olton, D. S., eds. Neurobiology of comparative cognition. Hillsdale, NJ: Erlbaum; 1990:179-204

7. Kesner, R. P.; Baker, T. B. A two-process model of opiate tolerance. In: Martinez, J. L. Jr.; Jensen, R. A.; Messing, R. B.; Rigter, H.; MeGaugh, J. L., eds. Endogenous peptides and learning and memory processes. New York: Academic Press; 1991:479-518.

8. Kesnér, R. P.; Bolland, B. L.; Dakis, M. Memory for spatial locations, motor responses, and objects: Triple dissociation among the hippocampus, caudate nucleus, and extrastriate visual cortex. Exp. Brain Res. 93:462-470; 1993.

9. Kesner, R. P.; Farnsworth, G.; DiMattia, B. V. Doubledissociation of egocentric and allocentric space following medial prefrontal and parietal cortex lesions in the rat. Behav. Neurosci. $103: 956-961 ; 1989$
10. Maisonneuve, I. M.; Keller R. W., Jr.; Glick, S. D. Interactions between ibogaine, a potential anti-addictive agent, and morphine: An in vivo microdialysis study. Eur. J. Pharmacol. 199:35-42, 1991.

11. Maisonneuve, I. M.; Rossman, K. L.; Keller R. W. Jr.; Glick, S. D. Acute and prolonged effects of ibogaine on brain dopamine metabolism and morphine-induced locomotor activity in rats. Brain Res. 575:69-73; 1992.

12. Markou, A.; Weiss, F.; Gold, L. H.; Caine, S. B.; Schulteis, G.; Koob, G. F. Animal models of drug craving. Psychopharmacology 112:163-182; 1993 .

13. O'Hearn, E.; Long, D. B.; Molliver, M. E. Ibogaine induces glial activation in parasagittal zones of the cerebellum. Neuroreport 4 : 299-302; 1993.

14. Robinson, T. E.; Berridge, K. C. The neural basis of drug craving: An incentive-sensitization theory of addiction. Brain Res. Rev. 18:247-291; 1993.

15. Sershen, H.; Hashim, A.; Lajtha, A. Ibogaine reduces preference for cocaine consumption in C57BL/6By mice. Pharmacol. Biochem. Behav. 47:13-19; 1994.

16. Siegel, $S$. The role of conditioning in drug tolerance and addiction. In: Keehn, J. D., ed. Psychopathology in animals, research and clinical implications. New York: Academic Press; 1979:143165.

17. Squire, L. R. Memory and the hippocampus: $\Lambda$ synthesis of the findings with rats, monkeys and humans. Psychol. Rev. 99:195$231 ; 1992$

18. Stevens, K. E.; Shiotsu, G.; Stein, L. Hippocampal $\mu$-receptors mediate opioid reinforcement in the $\mathrm{CA}_{3}$ region. Brain Res. 545: $8-16 ; 1991$. 